\title{
IZABELA LIPIŃSKA
}

\section{Z prawnej problematyki dobrostanu zwierząt gospodarskich}

\section{Wprowadzenie}

Punktem wyjścia rozważań jest założenie, że każde zwierzę jest zdolne do odczuwania cierpienia i powinno być traktowane przez człowieka we właściwy sposób, zależny od gatunku i rasy. Według Rezolucji z 4 lipca 2012 r. w sprawie strategii Unii Europejskiej w zakresie ochrony i dobrostanu zwierząt na lata $2012-2015^{1}$ wysoki poziom dobrostanu jest elementem zrównoważonego rozwoju i istotnym czynnikiem ochrony zdrowia zwierząt, a także zdrowia publicznego oraz produktywności i konkurencyjności sektora hodowli w Europie. Z tego powodu jest on cennym dobrem, które powinno podlegać szczególnej ochronie. Są nią otoczone w szczególności te osobniki, które pośrednio bądź bezpośrednio biorą udział w procesie produkcji zwierzęcej.

Problematyka dobrostanu podejmowana jest na płaszczyźnie różnych nauk, jak np. ekonomii, zootechniki, weterynarii, etyki, w tym także prawa. Właściwe warunki bytowania zwierząt są przedmiotem regulacji prawnych o zasięgu zarówno światowym, unijnym, jak i krajowym. Mają one na celu zapewnienie odpowiedniego ich traktowania w toku produkcji. Adresatami norm prawnych są zarówno producenci rolni, podmioty zajmujące się transportem zwierząt, ich ubojem, jak i organy administracji państwowej, którym powierzono funkcje kontrolne w tym zakresie.

Prawna regulacja dotycząca ochrony zwierząt ma pewną tradycję ${ }^{2} \mathrm{Na}$ szczeblu międzynarodowym była podejmowana już na początku XX w.,

${ }^{1}$ P7_TA(2012)0290.

2 Piszą na ten temat np. J. Białocerkiewicz, Prawny status zwierząt. Prawa zwierząt czy prawna ochrona zwierząt, Toruń 2005; I. Lazarii-Pawłowska, Zwierzę nie jest rzecza, w: P. J. Smoczyński 
czego przykładem może być Konwencja o ochronie ptaków pożytecznych dla rolnictwa z 1902 r. $^{3}$ Przewiduje ona m.in. obowiązek sygnatariuszy do wdrożenia do krajowych porządków prawnych regulacji mających na celu zakaz ich chwytania, zabijania i obrotu żywymi okazami, jak i ich gniazdami oraz pisklętami.

Istotne znaczenie dla podjęcia kwestii dobrostanu zwierząt ma raport opracowany przez komisję Brambella w 1965 r. Autorzy zawarli w nim postulat, że zwierzętom udomowionym przez człowieka pod względem warunków utrzymania powinno przysługiwać „pięć wolności” (five freedoms), $\mathrm{tj}$. :

- wolność od głodu, pragnienia i niedożywienia przez zapewnienie dostępu do świeżej wody i pokarmu, który utrzyma zwierzęta w zdrowiu i sile,

- wolność od urazów psychicznych i bólu przez zapewnienie odpowiedniego schronienia i miejsca odpoczynku,

- wolność od bólu, ran i chorób dzięki zapobieganiu, szybkiej diagnozie i leczeniu,

- wolność do wyrażania naturalnego zachowania przez zapewnienie odpowiedniej przestrzeni, warunków i towarzystwa innych zwierząt tego samego gatunku,

- wolność od strachu i stresu przez zapewnienie opieki i traktowanie, które nie powoduje psychicznego cierpienia zwierząt ${ }^{4}$.

Wskazane wolności, które jednocześnie należy rozumieć jako wartości, stały się powszechnie akceptowaną podstawą oceny dobrostanu. Stanowią one fundament rozwiązań legislacyjnych i ciągłych badań nad doskonaleniem warunków utrzymania zwierząt gospodarskich z punktu widzenia ich potrzeb.

Wydaje się, że sformułowane w raporcie treści „pobudziły” działania prawodawcze w Europie. Ich efektem było m.in. sformułowanie rekomendacji w zakresie transportu poszczególnych gatunków zwierząt ze szczegól-

(red.), Etyka. Pisma wybrane, Wrocław-Warszawa-Kraków 1992; A. Breczko, Od rzeczy do podmiotu, czyli praktyczne implikacje etyki ochrony zwierzat, „Białostockie Studia Prawnicze” 2013, z. 14.

${ }^{3}$ Oświadczenie rządowe z 21 lipca 1932 r. w sprawie przystąpienia Polski do konwencji o ochronie ptaków pożytecznych dla rolnictwa, podpisanej w Paryżu dnia 19 marca 1902 r., Dz. U. 1932, Nr 67, poz. 625.

${ }^{4}$ Tak np. S. P. McCulloch, A critique of FAWC's five freedoms as a framework for the fnalysis of animal welfare, ,Journal of Agricultural and Environmental Ethics” 26, 2013, s. 959975; I. Veissier et al., European approaches to ensure good animal welfare, „Applied Animal Behavior Science” 113, 2008, s. 279-297; M. Lipiński, Bioinżynieria produkcji mleka surowego, Poznań 2012, s. 31 i n. 
nym uwzględnieniem ich biologicznej charakterystyki, a także przyjęcie Europejskiej konwencji o ochronie zwierząt hodowlanych i gospodarskich w 1976 r. ${ }^{5}$ Jej sygnatariusze zobowiązali się do ustanowienia wspólnych norm prawnych odnośnie do pomieszczeń, żywienia i opieki zgodnych z potrzebami zwierząt oraz mających zapewnić im ochronę w warunkach nowoczesnych systemów intensywnego chowu. Konwencja wskazała ponadto konieczność uwzględniania wymagań bytowych zwierząt podczas opracowywania i wdrażania przepisów europejskich. Jej doniosłość, jak i postulaty w niej wyrażone zostały zawarte w wydanej przez Radę Europejską decyzji nr 78/923/EWG ${ }^{6}$. Wynika z jej treści, że ochrona zwierząt nie jest sama w sobie jednym $\mathrm{z}$ celów Wspólnoty. Jednakże Rada dostrzegła pewną zależność między ochroną zwierząt hodowlanych i gospodarskich a funkcjonowaniem wspólnego rynku w aspekcie nierównych warunków konkurencji. Na te ostatnie wpływ miało niejednolite podejście legislacyjne państw członkowskich, które skutkowało rozbieżnymi normami prawnymi.

Na poziomie wspólnotowym kwestia dobrostanu zwierząt jako „wartość" została podjęta także w traktacie amsterdamskim w 1997 r., do którego przyjęto Protokół dodatkowy o ochronie i dobrym traktowaniu zwierząt $^{7}$. Miał on znamienny wpływ na późniejszy proces legislacyjny. Ranga omawianej problematyki została także dostrzeżona przez Parlament Europejski, który w 2006 r. przyjął Wspólnotowy plan działań na rzecz ochrony i dobrostanu zwierząt ${ }^{8}$. Wyraził $\mathrm{w}$ nim swe przekonanie, że ochrona zwierząt jest wyrazem człowieczeństwa oraz wyzwaniem dla europejskiej cywilizacji i kultury ${ }^{9}$. Stwierdzenie to zostało wielokrotnie powtórzone w innych urzędowych dokumentach.

Podjęta problematyka wydaje się niezmiernie istotna, chociażby ze względu na możliwość zastosowania wielu podjeść badawczych. Traktowanie zwierzęcia jako istoty żywej implikuje jednocześnie konieczność stworzenia dla niej określonej ochrony prawnej. Staje się ono zatem

${ }^{5}$ Dz. U. Nr 104, poz. 665.

${ }^{6}$ Decyzja Rady z 19 czerwca 1978 r. dotycząca zawarcia Europejskiej Konwencji o ochronie zwierząt hodowlanych i gospodarskich (78/923/EWG), Dz. Urz. L 323 z 17 listopada 1978 r., s. 12-13.

${ }^{7}$ Zob. http://biurose.sejm.gov.pl/teksty/i-573.htm [dostęp: 18.05.2015].

${ }^{8}$ Komunikat Komisji do Parlamentu Europejskiego i Rady w sprawie Wspólnotowego planu działań dotyczącego ochrony i dobrostanu zwierząt na lata 2006-2010, Bruksela, 23.1.2006, KOM (2006).

${ }^{9}$ Pisze na ten temat J. Wojciechowski, Ochrona zwierzat $w$ UE - w dobrym kierunku zbyt matymi krokami, w: T. Gardocka, A. Gruszczyńska (red.), Status zwierzęcia. Zagadnienia filozoficzne i prawne, Toruń 2012, s. 291-294. 
szczególnym przedmiotem prawa. Dodatkowo jeżeli potraktujemy je jako część środowiska naturalnego, to nabywa ono pewnej wartości.

Celem artykułu jest próba udzielenia odpowiedzi na pytanie, w jakim stopniu regulacja prawna zapewnia dobrostan zwierząt. By na nie odpowiedzieć, należy w pierwszej kolejności określić pojęcie i zakres dobrostanu zwierząt. $Z$ uwagi na to, że zagadnienia te są podejmowane na wielu poziomach, konieczne jest przedstawienie unijnych ram prawnych o charakterze ogólnym, a następnie wskazanie zakres regulacji, który został pozostawiony jurysdykcji państw członkowskich.

Ograniczone ramy artykułu nie pozwalają na uwzględnienie wszystkich aspektów związanych $\mathrm{z}$ poruszaną problematyką, dlatego analizie zostaną poddane tylko wybrane akty normatywne.

\section{Pojęcie dobrostanu zwierząt}

Zakres dobrostanu zwierząt jest bardzo szeroki. Jego materia powoduje, że trudno jest sprecyzować jednolitą definicję. W szczególności może ona być wypadkową zarówno cech danego zwierzęcia, jak i celów, jakie ma ono spełnić w stosunku do oczekiwań człowieka. Przede wszystkim jego przedmiotem są zwierzęta trzymane w celu produkcji żywności, produktów pochodnych, jak np. futer, wełny, skór, a także wykorzystywane do innych celów $\mathrm{w}$ rolnictwie. Ponadto zalicza się do tej grupy także zwierzęta hodowlane przeznaczane do reprodukcji. Chodzi tu o zwierzęta gospodarskie o szczególnych walorach użytkowych trzymanych jako materiał zarodowy.

Zgodnie z Europejską konwencją o ochronie zwierząt gospodarskich i hodowlanych z 1976 r. dobrostan jest spełnieniem specyficznych gatunkowych potrzeb zwierząt z zakresu fizjologii, etologii i zdrowia. Warto dodać, że tak rozumiany w latach siedemdziesiątych dobrostan nadal odzwierciedla światowe kierunki w kształtowaniu warunków życia zwierząt gospodarskich. Jednakże nie doczekał się on jednolitej legalnej definicji. Bardzo często prawodawca posługuje się tym terminem, traktując go w sposób potoczny, jako pewien „stan”. Przykładem może być podejście wskazane w art. 12g pkt 2 ustawy z 21 sierpnia 1997 r. o ochronie zwierzą ${ }^{10} \mathrm{w}$ zakresie kontroli humanitarnego traktowania dokonywanej przez urzędowego lekarza weterynarii. Ustawodawca zakłada, że dobrostan mo-

${ }^{10}$ T.jedn.: Dz. U. 2013, poz. 856 ze zm. 
że mieć niski bądź wysoki poziom, ale nie podejmuje próby sformułowania jego zakresu. Takie podejście może wielokrotnie prowadzić do niepożądanego zachowania człowieka względem zwierzęcia. Ponadto w omawianym akcie prawnym ustawodawca, pomijając definicję dobrostanu, wskazuje jednak pewien zbór czynności, jakie powinien podejmować producent rolny. Należy do nich przede wszystkim zapewnienie opieki i właściwych warunków bytowania zwierzętom gospodarskim. Rozumie się przez nie takie warunki, które nie będą powodowały urazów i uszkodzeń ciała lub innych cierpień (art. 12 ustawy pkt 1).

Jednoznacznego podejścia do dobrostanu nie wniosło także orzeczenie Trybunału Konstytucyjnego z 10 grudnia 2014 r. w sprawie uboju rytualnego ${ }^{11}$. Trybunał potraktował dobrostan jako „rację” ekonomiczną i odmówił jego uznania za kategorię moralną, dopuszczając tym samym stosowanie praktyk, które przysparzają zbędnego cierpienia zwierzętom. $Z$ dokonanej przez niego wykładni wynika także, że ochrona zwierząt nie ma waloru etycznego, a mieści się jedynie w ramach ochrony środowiska naturalnego.

Zupełnie inne podejście reprezentuje J. Mroczek. Otóż uważa on, że punktem wyjścia w pojmowaniu definicji dobrostanu jest prawo zwierząt do humanitarnego traktowania, zgodnego $\mathrm{z}$ ich naturą, ponieważ zwierzęta również doświadczają emocje ${ }^{12}$. Takie stanowisko zostało chociażby przyjęte we wspomnianej ustawie o ochronie zwierząt. Otóż zgodnie z art. 1 tejże ustawy zwierzę, jako istota żyjąca, zdolna do odczuwania cierpienia, nie jest rzeczą. Człowiek jest mu winien poszanowanie, ochronę i opiekę ${ }^{13}$.

Dobrostan może być także postrzegany jako jeden z elementów właściwego zarządzania produkcją rolną, obok ochrony środowiska naturalnego oraz szeroko rozumianego zdrowia publicznego. Należy go traktować jako zespół warunków określających potrzeby biologiczne i behawioralne zwierząt, które umożliwiają „objawianie” w pełni ich możliwości genetycznych.

Z kolei za Zootechnicznym niezbędnikiem terminologicznym przez dobrostan należy rozumieć zapewnienie zwierzętom optymalnych warunków bytowania, na które składają się prawidłowe rozwiązania techniczne pomieszczeń i stanowisk, ich właściwy mikroklimat (temperatura, wilgotność i ruch powietrza) $)^{14}$.

${ }^{11} \mathrm{~K} 52 / 13$.

${ }^{12}$ Zob. J. Mroczek, Dobrostan zwierząt jako element retardacji przeksztatcania zasobów w produkcji zwierzęcej, „Inżynieria Ekologiczna” nr 34, 2013, s. 182.

${ }^{13} \mathrm{Na}$ ten temat pisze A. Breczko, op. cit., s. 17-28.

${ }^{14}$ Tak H. Pawlak, M. Lipiński, Zootechniczny niezbędnik terminologiczny, Poznań 2011, s. 37. 
Dobrostan ma znaczący wpływ na samopoczucie zwierząt ich długowieczność oraz wydajność, składa się nań bowiem przede wszystkim prawidłowy stan zdrowia fizycznego i psychicznego przejawiający się właściwymi mu zachowaniami behawioralnymi, co zapewnia harmonijne osadzenie go w przyjaznym środowisku. Zwierzęta gospodarskie powinny być tak żywione, otoczone fachową opieką i utrzymywane w pomieszczeniach inwentarskich, aby były zaspokojone ich potrzeby.

Dobrostan oznacza również taki stan, w którym zwierzę odczuwa pozytywne emocje, to jest przyjemność i zadowolenie, a nie tylko negatywne, takie jak strach i frustracja. $Z$ tego względu istotnym jego elementem jest zapewnienie zwierzętom towarzystwa innych osobników oraz właściwej przestrzeni życiowej. Z kolei J. Zegar traktuje dobrostan jako stan harmonii między zwierzęciem a środowiskiem, w którym ono przebywa, dlatego podstawowe znaczenie ma jakość środowiska hodowlanego ${ }^{15}$.

Do wymienionych powyżej atrybutów dobrostanu Światowa Organizacja Zdrowia Zwierząt zalicza także odpowiednią opiekę weterynaryjną, zarządzanie produkcją i chowem zwierząt oraz humanitarne metody ich zabijania $^{16}$.

Nieco inne podejście do dobrostanu przedstawia D. Broom. Otóż uważa on, że przez pojęcie to należy rozumieć sposób „sprostania” warunkom bytowym i środowisku, w jakich zwierzę przebywa. Jest to więc stan prawidłowej dynamiki organizmu zwierzęcia, a oddziałują nań czynniki zewnętrzne i wewnętrzne, w którym ono się znajduje. Zatem dobrostan jest zawsze, ale może on mieć różny zakres i wpływ na jednostkę ${ }^{17}$.

Warto podkreślić, że dobrostan ma znaczący wpływ nie tylko na samopoczucie zwierząt bądź ich długowieczność, ale również wydajność, co jest niezmiernie istotne w ekonomice produkcji. Zapewnienie zwierzętom jego odpowiedniego poziomu jest warunkiem sine qua non osiągnięcia oczekiwanej opłacalności chowu. Można zatem stwierdzić, że w tym ujęciu dobrostan zwierząt jest instrumentem ekonomicznym, dla którego sformułowane zostały normy prawne. $\mathrm{Z}$ analizy przepisów w odniesieniu do poszczególnych gatunków zwierząt wynika bowiem, że ustanowione

${ }^{15}$ Tak J. Zegar, Zrównoważenie polskiego rolnictwa. Powszechny Spis Rolny, Warszawa 2013, s. 17.

${ }^{16}$ Zob. A new definition for the Terrestrial Animal Health Code: 'animal welfare', Terrestrial Animal Health Code. OIE. Retrieved 20 December 2013, s. 18.

${ }^{17}$ Zob. D. M. Broom, Animal welfare defined in terms of attempts to cope with the environment, „Acta Agriculturae Scandinavica. Section A, Animal Science” 1996, nr 27, s. 22-28. 
w nich normy nie tylko pozwalają poszczególnym osobnikom na ich racjonalny i zgodny z fizjologią byt, ale umożliwiają pozyskiwanie najbardziej oczekiwanych wyników ekonomicznych (np. maksymalnego przyrostu trzody chlewnej czy zawartości tłuszczu i białka w mleku). Dobrostan zwierząt gospodarskich „mieści” się w granicach uzasadnionych ekonomicznie dla danej jednostki wytwórczej. Ponadto metody produkcji z zachowaniem reguł dobrostanu, tym różnią się od powszechnie stosowanych, że silnie eksponują samopoczucie zwierząt $w$ ich środowisku hodowlanym.

Jak zauważa J. Zegar, wielkotowarowa hodowla i chów zwierząt mają trudności ze spełnieniem wymogów dobrostanu zwierząt, które najłatwiej spełniają system półintensywny, rolnictwo ekologiczne, integrowane i biodynamiczne $^{18}$. Wielofunkcyjność rolnictwa, uznawana obecnie za podstawową cechę nowej strategii rozwoju, zdecydowanie wzmacnia mechanizmy rozwoju zrównoważonego i sprzyja dostarczaniu dóbr publicznych przez rolnictwo i obszary wiejskie. Do tych dóbr zalicza się dobra środowiskowe oraz dobra społeczne, czyli dobrostan zwierząt.

\section{Dobrostan zwierząt w prawie Unii Europejskiej}

Problematyka dobrostanu zwierząt w Unii Europejskiej została podjęta 40 lat temu. Pierwszym aktem wydanym w tym zakresie była dyrektywa 74/577/EWG z 18 listopada 1974 r. w sprawie przedubojowego oszałamiania zwierząt ${ }^{19}$. Na jej podstawie prawodawca nałożył na państwa członkowskie obowiązek przyjęcia odpowiednich norm prawnych, które będą prowadziły do ograniczenia cierpienia zwierząt w czasie uboju. Jednakże zwrócenie uwagi na problematykę dobrostanu miało wówczas jedynie charakter incydentalny. Jak zaznaczono wcześniej, zainteresowanie prawodawcy omawianą problematyką zostało pobudzone dopiero przez przyjmowane zobowiązania na arenie międzynarodowej. Wówczas ustalone zostały ogólne zagadnienia dotyczące trzymania zwierząt gospodarskich (decyzja Rady nr 78/923) ${ }^{20}$, zasady transportu oraz regulacje odnoszące się do poszczególnych typów produkcji, jak np. cieląt (dyrektywa

\footnotetext{
${ }^{18}$ Tak J. Zegar, op. cit., s. 18.

${ }^{19}$ Dz. Urz. L 316 z 26 listopada 1974 r., s. 10.

${ }^{20}$ Decyzja Rady z 19 czerwca 1978 r. dotycząca zawarcia Europejskiej konwencji o ochronie zwierząt hodowlanych i gospodarskich, Dz. Urz. L 323 z 17 listopada 1978 r., s. 12-13.
} 
Rady nr 91/629)21, świń (dyrektywa Rady nr 91/630)22 czy kur niosek (dyrektywa Rady nr 88/166) ${ }^{23}$.

Istotny wpływ na szersze podejście do dobrostanu zwierząt i rozwój jego prawodawstwa miał dokonany w 2002 r. średniookresowy przegląd WPR $^{24}$ oraz wdrażana od 2005 r. reforma rolna. Wprowadziła ona m.in. powiązanie otrzymywania płatności bezpośrednich i płatności specyficznych dla określonych kierunków produkcji z obowiązkiem spełniania określonych standardów przez gospodarstwo zwanych minimalnymi wymogami wzajemnej zgodności (cross-compliance), których jednym z elementów było przestrzeganie dobrostanu zwierząt.

W prawie pierwotnym omawiana problematyka została ujęta dopiero w treści Traktatu o funkcjonowaniu Unii Europejskiej. Na podstawie art. 13 TfUE przy formułowaniu i wykonywaniu wspólnej polityki rolnej, rybołówstwa i transportu, państwa członkowskie w pełni zobowiązują się do uwzględnianie wymagań $\mathrm{w}$ zakresie dobrostanu zwierząt jako istot zdolnych do odczuwania, przy równoczesnym przestrzeganiu przepisów prawnych i administracyjnych oraz zwyczajów państw członkowskich związanych w szczególności z obyczajami religijnymi, tradycjami kulturowymi i dziedzictwem regionalnym.

Jednakże praktyka państw członkowskich daleka była od jednolitego podejścia do problemu dobrostanu zwierząt. Występowało wiele różnic co do spełniania jego podstawowych zasad ${ }^{25}$. Wynikało to m.in. z kilku względów. Przede wszystkim w obszarze UE występowała i nadal występuje duża niejednorodność środowisk rolniczych poszczególnych państw, które różnią się od siebie zarówno sytuacją społeczną, jak i ekonomiczną. Dodatkowo istnieją także aspekty kulturowe w podejściu do dobrostanu, jak chociażby kwestia uboju rytualnego dla niektórych wyznań. Z tego powodu wiele elementów dobrostanu w ogólne nie było realizowanych. Niektóre państwa członkowskie nie egzekwowały norm unijnych, w tym niedostatecznie przekazywały informacje konsumentom w kwestiach metod produkcji i jej wpływu na dobrostan zwierząt. Z tego powodu Komisja

${ }^{21}$ Dyrektywa Rady z 19 listopada 1991 r. ustanawiająca minimalne normy ochrony cieląt, Dz. Urz. UE L 340 z 11 grudnia 1991 r., s. 28.

${ }^{22}$ Dyrektywa Rady z 19 listopada 1991 r. ustanawiająca minimalne normy ochrony świń, Dz. Urz. UE L 340 z 11 grudnia 1991 r., s. 33-38.

${ }^{23}$ Dyrektywa Rady nr 88/166 z 7 marca 1988 r. ustanawiająca minimalne normy ochrony kur niosek, Dz. Urz. UE L 74 z 19 marca 1988 r., s. 83-87.

${ }^{24}$ Pisze na ten temat D. Stankiewicz, Reforma Wspólnej Polityki Rolnej UE, Kancelaria Sejmu, Biuro Studiów i Ekspertyz, 2003, s. 1 i n.

${ }^{25}$ Por. I. Veissier et al., op. cit., s. 283. 
rozpoczęła prace nad jego poprawą i udoskonaleniem, czego efektem było sfomułowanie tzw. Planu działań na rzecz dobrostanu zwierząt na lata 2006-2010 ${ }^{26}$. Plan przewidywał dość przejrzyste określenie unijnych norm prawnych i zawierał propozycje w obszarach, w których są one niewystarczające. W ramach podstawowych obszarów działań uwzględniono m.in. podnoszenie wymogów minimalnych, wprowadzenie wskaźników dobrostanu, lepsze informowanie profesjonalistów i opinii publicznej oraz wsparcie inicjatyw międzynarodowych na rzecz ochrony zwierząt ${ }^{27}$.

Dokonując ewaluacji wykonania planu, Parlament Europejski uznał jego realizację za satysfakcjonującą ${ }^{28}$. Niemniej zabrakło w nim niezbędnych rozwiązań co do transportu zwierząt oraz powiązanej z nim kwestii rozwoju satelitarnego systemu monitorowania ich przewozu, a także zagadnień nieprzestrzegania przez wielu hodowców trzody chlewnej dyrektywy 2008/120/WE ustanawiającej minimalne normy ochrony świń ${ }^{29}$. Ponadto Parlament zwrócił szczególną uwagę na fakt, że zdrowie zwierząt i dobra gospodarka hodowlana mają duże znaczenie dla rozwoju rolnictwa, jego konkurencyjności oraz „marki” europejskich producentów rolnych, o ile przestrzegane są przepisy prawne.

Kontynuacją prac $\mathrm{w}$ zakresie stosowania norm dobrostanu zwierząt jest Strategia na lata 2012-2015 ${ }^{30}$. Do jej fundamentalnych założeń należy wprowadzenie bardziej precyzyjnych, ale i uproszczonych rozwiązań w zakresie dobrostanu zwierząt ${ }^{31}$. Dotyczą one m.in. zagwarantowania stosowania wskaźników dobrostanu zwierząt opartych na wynikach badań naukowych, zmiany zasad informowania konsumentów o dobrostanie zwierząt, ze szczególnym uwzględnieniem przejrzystości i naukowej wiarygodności jego oświadczeń. Ponadto strategia przewiduje wspieranie

${ }^{26}$ Komunikat Komisji do Parlamentu Europejskiego i Rady z 23 stycznia 2006 r. w sprawie wspólnotowego planu działań dotyczącego ochrony i dobrostanu zwierząt w latach 20062010, KOM (2006) 13, Dz. Urz. UE C 49 z 28 lutego 2006 r.

${ }^{27}$ Zob. http://europa.eu/legislation_summaries/food_safety/animal_welfare/f82003_pl.htm [dostęp: 14.04.2015].

${ }^{28}$ Ocena i podsumowanie wspólnotowego planu działań dotyczącego dobrostanu zwierząt na lata 2006-2010. Rezolucja Parlamentu Europejskiego z 5 maja 2010 r. w sprawie ewaluacji i oceny Wspólnotowego planu działań dotyczącego dobrostanu zwierząt na lata 2006-2010 (2009/2202 (INI)), P7_TA(2010)0130.

${ }^{29}$ Dyrektywa Rady 2008/120/WE z 18 grudnia 2008 r. ustanawiająca minimalne normy ochrony świń, Dz. Urz. UE L 47 z 18 lutego 2009 r., s. 5-13.

${ }^{30}$ Strategia w zakresie ochrony i dobrostanu zwierząt. Rezolucja Parlamentu Europejskiego z 4 lipca 2012 r. w sprawie strategii Unii Europejskiej w zakresie ochrony i dobrostanu zwierząt na lata 2012-2015, (2012/2043(INI)) P7_TA(2012)0290.

${ }^{31}$ Zob. Strategia UE w zakresie dobrostanu zwierząt 2012-2015, http://ec.europa.eu/food/ animal/welfare/docs/brochure_aw_strategy_pl.pdf [dostęp: 20.03.2015]. 
państw członkowskich w poprawie przestrzegania prawa, przekazywanie konsumentom i opinii publicznej odpowiednich informacji o sposobach postępowania ze zwierzętami gospodarskimi, a także optymalizację tzw. efektów synergii Wspólnej Polityki Rolnej, które dotyczą zasad wzajemnej zgodności, rozwoju obszarów wiejskich, działań promocyjnych, polityki jakości i rolnictwa ekologicznego ${ }^{32}$.

Szczególne zasady dobrostanu zostały ujęte całościowo i obejmują wymogi ogólne dotyczące wszystkich trzymanych zwierząt gospodarskich bez względu na gatunek i ilość zwierząt w gospodarstwie. Należą do nich: konieczność stosowania dozwolonych technologii chowu i hodowli zwierząt, odpowiednie przygotowanie personelu obsługującego zwierzęta, dozór i kontrola nad nimi, odpowiednie przygotowanie i utrzymanie budynków oraz pomieszczeń inwentarskich, swoboda ruchu zwierząt, a także właściwe postępowanie ze zwierzętami chorymi (jak np. wykonywanie zabiegów $)^{33}$. Prawodawca ustanowił także normy sektorowe dla poszczególnych gatunków, jak np. cieląt oraz świń.

Warto podkreślić, że dobrostan zwierząt jest jednym z priorytetów realizowanej Wspólnej Polityki Rolnej. Wpływa on bowiem na zapewnienie zrównoważonego rozwoju obszarów wiejskich. W rozporządzeniu nr 1305/2013 ${ }^{34}$ prawodawca podkreśla konieczność zachęcania producentów rolnych do przyjmowania wysokich norm w zakresie dobrostanu zwierząt nawet takich, które wykraczają poza normy obowiązkowe - przez udzielanie wsparcia finansowego. W szczególności jego promowanie ma pośrednio przyczyniać się do wspierania organizacji łańcucha dostaw żywności.

Odpowiednio na mocy art. 33 rozporządzenia nr 1305/2013 przewidziane są płatności z tytułu dobrostanu zwierząt. W ramach tego działania wsparcia udziela się rolnikom, którzy dobrowolnie podejmują się przyjęcia jednego lub większej liczby zobowiązań dotyczących dobrostanu zwierząt ${ }^{35}$.

${ }^{32}$ Zob. A. Bartkowiak, Ł. Namyślak, P. Mielcarek, Działania strategiczne w zakresie dobrostanu zwierzat jako element zrównoważonego rozwoju rolnictwa, ,Problemy Inżynierii Rolniczej" 2012, z. 1, s. 99-104.

${ }_{33}$ Zob. Broszura informacyjna MRiRW w zakresie wymogów wzajemnej zgodności. http://www.minrol.gov.pl/Wsparcie-rolnictwa-i-rybolowstwa/Platnosci-ezposrednie/Archiwum/ Normy-i-Wymogi-Wzajemnej-Zgodnosci-cross-compliance/Nowe-wymogi-wzajemnej-zgodnosci -obowiazujace-od-2013-roku.

${ }^{34}$ Rozporządzenie Parlamentu Europejskiego i Rady (UE) nr 1305/2013 z 17 grudnia 2013 r. w sprawie wsparcia rozwoju obszarów wiejskich przez Europejski Fundusz Rolny na rzecz Rozwoju Obszarów Wiejskich (EFRROW) i uchylające rozporządzenie Rady (WE) nr 1698/2005, Dz. Urz. UE L 347 z 20 grudnia 2013 r., s. 487.

${ }_{35}$ Adresatami wsparcia są tylko rolnicy aktywnymi zawodowo w rozumieniu art. 9 rozporządzenia nr 1307/2013. 
Oczywiście omawiane płatności obejmują jedynie te zobowiązania, które wykraczają poza odpowiednie obowiązkowe normy, a są one podejmowane na okres od jednego do siedmiu lat $\mathrm{z}$ możliwością przedłużenia.

Omawiane płatności przyznawane są corocznie. Ich celem jest rekompensata rolnikom całość lub część dodatkowych kosztów i dochodów utraconych $\mathrm{w}$ wyniku podjętego zobowiązania. W razie konieczności płatności te mogą również obejmować koszty transakcyjne do wartości maksymalnie $20 \%$ premii wypłaconej z tytułu zobowiązań dotyczących dobrostanu zwierząt.

Wsparcie ogranicza się do wysokości maksymalnej kwoty 500 euro na dużą jednostkę przeliczeniową inwentarza (Załącznik II rozporządzenia nr 1305/2013). Ponadto na mocy art. 83 omawianego rozporządzenia Komisja Europejska jest uprawniona do przyjmowania aktów delegowanych, które mogą przewidywać bardziej rygorystyczne normy w zakresie metod produkcji w odniesieniu do dobrostanu zwierząt.

W utrzymywaniu dobrostanu zwierząt, które jest zależne od woli człowieka, niezmiernie ważnym aspektem jest jego weryfikacja i nadzór. Zagadnienia te zostały zawarte w rozporządzeniu nr 882/2004 Parlamentu Europejskiego i Rady z 29 kwietnia 2004 r. w sprawie kontroli urzędowych przeprowadzanych $\mathrm{w}$ celu sprawdzenia zgodności z prawem paszowym i żywnościowym oraz regułami dotyczącymi zdrowia zwierząt i dobrostanu zwierząt ${ }^{36}$. U podstaw tego aktu normatywnego leży założenie, że zdrowie zwierząt i ich dobrostan są istotnymi czynnikami, które przyczyniają się do podniesienia jakości i bezpieczeństwa żywności. $Z$ tego względu na państwach członkowskich leży obowiązek zarówno egzekwowania reguł dotyczących zdrowia zwierząt, ich dobrostanu, jak i monitorowania ich spełniania przez podmioty gospodarcze na wszystkich etapach produkcji, przetwarzania i dystrybucji. Dlatego zgodnie z art. 3 rozporządzenia $\mathrm{nr} 882 / 2004 \mathrm{w}$ każdym państwie powinny być organizowane kontrole urzędowe ${ }^{37}$. Zasady ich przeprowadzania i przede wszystkim powoływania właściwych organów zostały pozostawione ustawodawcy krajowemu.

${ }^{36}$ Dz. Urz. UE L 165 z 30 kwietnia 2004 r., s. 1.

${ }^{37}$ W 2010 r. Komisja Europejska przyjęła sprawozdanie w sprawie skuteczności i spójności kontroli sanitarnych i fitosanitarnych w odniesieniu do przywozu żywności, paszy, zwierząt i roślin. Jego efektem było zaproponowanie przez Komisję nowego aktu normatywnego. Jego treść nadal jest przedmiotem prac. Zob. Sprawozdanie Komisji dla Parlamentu Europejskiego i Rady w sprawie skuteczności i spójności sanitarnych i fitosanitarnych kontroli przywozu żywności, paszy, zwierząt i roślin, Bruksela, 21.12.2010, KOM (2010), 785, wersja ostateczna. 


\section{Dobrostan zwierząt gospodarskich w świetle prawa polskiego}

Podstawowym aktem prawnym regulującym byt zwierząt gospodarskich w Polsce jest ustawa o ochronie zwierząt z 20 sierpnia 1997 r. ${ }^{38}$ Ksztaltuje ona zarówno zasady ich trzymania, kwestie wdrażania nowych technik i technologii produkcji, jak i kompetencje organów administracji publicznej w zakresie czynności kontrolnych, a także ich współdziałania z odpowiednimi instytucjami i organizacjami krajowymi oraz międzynarodowymi. Kontrole, o których mowa, przeprowadza Inspekcja Weterynaryjna.

W dużej mierze zagadnienia związane $\mathrm{z}$ dobrostanem zwierząt w Polsce poddane zostały oddziaływaniu regulacji unijnej. Przykładem może być rozporządzenie Ministra Rolnictwa i Rozwoju Wsi z 15 lutego 2010 r. w sprawie wymagań i sposobu postępowania przy utrzymywaniu gatunków zwierząt gospodarskich, dla których normy ochrony zostały określone $\mathrm{w}$ przepisach Unii Europejskiej ${ }^{39}$. Określa ono wymagania i sposób postępowania przy chowie cieląt, świń i kur niosek. Kolejnym aktem wykonawczym jest rozporządzenie Ministra Rolnictwa i Rozwoju Wsi z 28 czerwca 2010 r. w sprawie minimalnych warunków utrzymywania gatunków zwierząt gospodarskich innych niż te, dla których normy ochrony zostały określone w przepisach Unii Europejskiej ${ }^{40}$. Odnosi się ono do minimalnych warunków bytowania bydła $\mathrm{z}$ wyjątkiem cieląt, koni, owiec, kóz, strusi, przepiórek, perlic, lisów polarnych, lisów pospolitych, jenotów, norek, tchórzy, królików, szynszyli, nutrii, jeleni, danieli oraz indyków, gęsi i kaczek. Oba akty wykonawcze kształtują wymogi dobrostanu uzależnione od gatunku zwierzęcia w zakresie: kwalifikacji osób obsługujących zwierzęta, opieki i kontroli zwierząt, przechowywania dokumentacji dotyczącej leczenia oraz hodowlanej, rejestru upadków, zapewnienia swobody ruchu zwierzętom, jakości budynków i pomieszczeń, w których przebywają zwierzęta (dostępna powierzchnia, pomieszczenia), zapewnienia zwierzętom właściwych warunków środowiskowych, karmienia i pojenia, postępowania ze zwierzętami chorymi, zranionymi oraz wykonywania zabiegów lekarsko-weterynaryjnych, sposobu ich przemieszczania oraz technologii stosowanych w chowie i hodowli zwierząt.

\footnotetext{
${ }^{38}$ T.jedn.: Dz. U. 2013, poz. 856.

${ }^{39}$ Dz. U. 2010, Nr 56, poz. 344 ze zm.

${ }^{40}$ Dz. U. 2010, Nr 116, poz. 778.
} 


\section{Podsumowanie}

Regulacja prawna z zakresu dobrostanu zwierząt jest bardzo rozległa i od strony instytucjonalnej kompletna. Obejmuje ona w sposób kompleksowy wszystkie zagadnienia, począwszy od utrzymania zwierząt w obrębie gospodarstwa rolnego, przez ich transport, po warunki uboju. W dużej mierze oddziałuje także na bezpieczeństwo żywności w odniesieniu chociażby do prawa paszowego oraz obowiązku przekazywania informacji konsumentom o produkcie. Chodzi tu o rzetelne informowanie o stosowanych metodach produkcji i ich wpływie na dobrostan ${ }^{41}$. Na poziomie unijnym prawodawca podjął próbę ujednolicenia rozproszonych standardów krajowych, tworząc jednolity rynek. Skutkuje to koniecznością dostosowania legislacji krajowej do licznych dyrektyw unijnych.

Przegląd ustawodawstwa unijnego i krajowego pozwala stwierdzić, że regulacja prawna zapewnia dobrostan zwierząt, niemniej jej stosowanie daje dużo do życzenia.

Po pierwsze, istnieje zbyt duża liczba aktów normatywnych, które powinny być stosowane przez ich adresatów. Ulokowanie omawianej problematyki dwu biegunowo - przez prawodawcę zarówno unijnego, jak i polskiego powoduje, że producenci rolni mają problemy z ich ustaleniem. Czego przykładem mogą być cytowane wcześniej dwa rodzime rozporządzenia kształtujące wymagania i sposoby postępowania przy utrzymywaniu gatunków zwierząt gospodarskich. Chodzi w szczególności o podział gatunków zwierząt na te, dla których normy ochrony zostały ustalone przepisami UE, i gatunków pozostałych. W obu przypadkach odnoszą się one np. do bydła, ale stosuje się jedno z nich w zależności od wieku zwierzęcia. Powoduje to małą przejrzystość regulacji, czego efektem mogą być zaniedbania po stronie adresatów. $Z$ tego względu konieczne jest dalsze uproszczenie $\mathrm{i}$ ujednolicenie norm $\mathrm{w}$ zakresie dobrostanu zwierząt. Uzasadnione wydaje się pozostawienie jurysdykcji państw członkowskich jedynie funkcji kontrolnych, przenosząc wszystkie zasady chowu i hodowli na poziom unijny. Umożliwi to zastosowanie jednolitego podejścia do omawianej problematyki, tak jak to zostało dokonane w przypadku transportu zwierząt.

Po drugie, producenci rolni nie zawsze dostrzegają potrzebę stosowania zasad dobrostanu zwierząt, skoro i tak osiągają pożądany wynik eko-

\footnotetext{
${ }^{41}$ Zob. np. J. Książkiewicz, Historia tuczu przymusowego drobiu wodnego na stluszczone watroby - aspekty badawcze i technologiczne, „Wiadomości Zootechniczne” 2006, nr 3, s. 82-87.
} 
nomiczny z prowadzonej produkcji. Dlatego konieczne wydaje się wprowadzenie jasnych zasad wspierania tych, którzy zapewniają podstawowe wymogi dobrostanu, oraz tych rolników, którzy utrzymują lepsze warunki bytowania, aniżeli wymaga prawodawca. Ogromną rolę odgrywa tu realizacja przyjętych celów Wspólnej Polityki Rolnej, instrumenty prawno-ekonomiczne bowiem, w szczególności finansowe w postaci wsparcia dla producentów rolnych, pozytywnie oddziałują na jego zabezpieczenie. $\mathrm{Z}$ drugiej strony powinien być również skuteczny system wykrywania i sankcjonowania podmiotów niestosujących się do przyjętych wymogów.

Po trzecie, obrót zwierzętami i żywnością pochodzenia zwierzęcego w warunkach otwartych granic w UE uzasadnił konieczność przeniesienia norm prawnych dobrostanu na poziom unijny. Jednakże pojawia się nowe zagrożenie w obliczu zawarcia Transatlantyckiego Porozumienia Handlowo-Inwestycyjnego - TTIP pomiędzy Stanami Zjednoczonymi Ameryki Północnej a Unią Europejską. Mianowicie chodzi tu o zasadnicze różnice w pojęciu dobrostanu zwierząt, szczególnie ich zdrowia, jak i w sposobach jego mierzalności oraz oceny. Przykładem tego może być chociażby kwestia wykorzystywania w USA techniki klonowania zwierząt w produkcji żywności ${ }^{42}$. Ponadto poszczególne stany mogą swobodnie tworzyć normy chroniące dobrostan zwierząt, jednakże państwa członkowskie UE nie mają instrumentów prawnych, które zakazują importu produktów pochodzących od krzywdzonych zwierząt. Zawarcie tego porozumienia w przyszłości może rodzić wiele problemów, dlatego konieczne jest określenie jednolitych i spójnych rozwiązań legislacyjnych, które będą zapewniały dobrostan zwierząt gospodarskich.

Po czwarte, bytowanie zwierząt jest przede wszystkim uzależnione od człowieka, jego świadomości i przygotowania. Odpowiednio upraszczanie unijnych norm prawnych dotyczących dobrostanu zwierząt powinno służyć jednocześnie podnoszeniu kompetencji osób zajmujących się zwierzętami.

Po piąte, dobrostan zwierząt ma wieloaspektowy wymiar pod względem naukowym, technicznym, etycznym, ekonomicznym i prawnym. Miarą jego oceny są różne wskaźniki, takie jak: zdrowie i parametry fizjologiczne, samopoczucie oraz - jak podkreślono wcześniej - uzyskiwane wyniki produkcyjne. $\mathrm{Z}$ tego też względu - co jest uwzględnianie w bieżą-

${ }^{42}$ Pisze na ten temat K. Leśkiewicz, Prawne aspekty klonowania zwierzą $i$ wprowadzania do obrotu klonów oraz żywności pochodzącej od klonów, „Przegląd Prawa Rolnego” 2014, nr 1, s. 199 i n. 
cej polityce UE - niezbędne jest opieranie przepisów prawnych, czy też standardów na najnowszych osiągnięciach technologicznych i naukowych. Dodatkowo przy formułowaniu nowych wytycznych dobrostanu konieczne będzie uwzględnienie kosztów dostosowawczych, operacyjnych, finansowych oraz administracyjnych, które są ponoszone przez rolników podczas dostosowywania produkcji do stawianych im wymogów.

\title{
THE LEGAL ISSUES OF FARM ANIMALS WELFARE
}

\author{
Sum mary
}

The article tackles the issue of farm animals welfare as a constituent factor of animal health protection and an important element of proper management of agricultural production. The starting point for the deliberations is an assumption that each animal is capable of the feeling of suffering and should therefore be treated in a proper way, relevant to its species and race. In the authoress' opinion the current legislation ensures animal welfare and covers in a comprehensive manner all respective issues starting from animal maintenance at a farm, through the transporting of animals, to the conditions of their slaughter. Further simplification and harmonisation of the existing legislative norms is nevertheless necessary, as well as formulation of clear principles of support to farmers who satisfy the basic requirements of animal welfare, and to those who maintain standards even higher than prescribed.

\section{DELLA PROBLEMATICA GIURIDICA NEL BENESSERE DEL BESTIAME}

\author{
Ri a s sunto
}

L'oggetto dell'articolo è il benessere del bestiame, il quale costituisce un fattore importante per la protezione della loro salute ed è uno degli elementi per servono a gestire la produzione agricola in modo corretto. Il punto di partenza per le considerazioni è costituito dal presupposto che ogni animale è capace di provare dolore e che l'uomo dovrebbe trattarlo in modo appropriato, a seconda della specie e razza. A parere dell'autrice, le norme di legge vigenti garantiscono il benessere degli animali. Esse abbracciano in maniera completa tutte le questioni a partire dal mantenimento del bestiame all'interno dell'azienda e il loro trasporto fino alla macellazione. Tuttavia, si rivela tuttora necessario apportare ulteriori semplificazioni e armonizzare le norme al riguardo, ma anche formulare chiare regole di sostegno agli agricoltori che stanno già garantendo il rispetto delle esigenze essenziali in materia di benessere ed anche a quelli che stanno già assicurando al bestiame le condizioni di vita migliori di quelle richieste dal legislatore. 